胃癌術後遠隔成績からみたリンパ節郭清の意義について

\begin{tabular}{lrrrrr}
\multicolumn{7}{c}{ 大阪大学第 2 外科 } \\
藤本 & 二郎 & 穀内 & 勇夫 & 宮本 & 徳廣 \\
田根 & 锒 & 塩崎 & 均 & 城戸 & 良弘 \\
小川 & 道雄 & 小川 & 嘉誉 & 森 & 武貞
\end{tabular}

\title{
PROGNOSTIC SIGNIFICANCE OF REGIONAL LYMPH NODES DISSECTION IN GASTRIC CANCER
}

\author{
Jiro FUJIMOTO, Isao KOKUNAI, Tokuhiro MIYAMOTO, \\ Satoshi TANE, Hitoshi SHIOZAKI, Yoshihiro KIDO, \\ Michio OGAWA, Yoshitaka OGAWA and Takesada MORI \\ Department of Surgery II, Faculty of Medicine, Osaka University
}

索引用語：胃癌術後遠隔成績, 胃癌リンパ節郭清, 期待生存率

はじめに

癌病巣の所属するリンパ節細胞には, 腫瘍細胞の増 殖を㧕制する biological な barrier が存在すると考え られておりここ barrier は動物実験においてはすで に実証されている1)。 ヒト胃癌切除術後の残存所属リ ンパ節の barrier としての機能の評価は, 従来手術時 に摘出したリンパ節の in vitroにおける免疫応答 能2) 4) や, その組織学的所見 ${ }^{4) 5} に よ り$ 類推されてはい るが, in vitroの免疫応答能についての記述が報告者 により少しずつ異っていること, そして摘出リンパ節 の抗腫瘍能は, 摘出した時点で, その患者への影響力 を失っていることる事実である。

そこで同一 stageの胃癌治癒切除術後患者につい $\tau, \mathrm{R}_{1}, \mathrm{R}_{2}, \mathrm{R}_{3}$ の郭清程度別に, その遠隔成績を比較す ることにより, 残存所属リンパ節の抗腫場能を評価し うるのではないかと考光, 以下の検討を行った。

\section{検索対象および方法}

検討の対象は，昭和38年より59年までの 22 年間に当 科で治癒切除を行った初回入院胃癌患者で 1,043 名, そ のうち361名の早期胃癌患者が含まれている.これらの

※第26回日消外総会シンポII：消化器癌リンパ節応答 とその郭清

$<1985$ 年11月 12 日受理 $>$ 別刷請求先 : 藤本 二郎

T553 大阪市福島区福島 $1-1-50$ 大阪大学医学 部第 2 外科
胃癌患者の胃癌取扱い規約に基づく stage 別および $\mathrm{R}$ 別の内訳は表 1 に示した。この stage 別拈よびR別の グループごとに, 生命表法6)にしたがい術後10年まで の累積生存率を算出し, 同一 stage の R別グループ相 互の比較を行った。症例数の少ない昜合には KaplanMeier 法7を用い生存率を求めた。生存率の算出にあ たり手術直接死亡例は除外していない.さらにコー ホート生存率8を用いて各グループの期待生存率を求 め, 前出の粗生存率をこの期待生存率で除することに より相対生存率 ${ }^{9)}$ を算出し, 各グループ相互の比較を 行った.

蛇足ながら相対生存率は観察対象者の珄・年龄に相 当する一般集団の生存率, すなわち期待生存率を考虑 した生存率で, 性・年龄の偏りが補正されるとともに, 原疾患以外の他病死の問題もある程度解決でさるとさ れている。

結 果
リンパ節転移のない stage I 胃癌（453例）の絶対治

表 1 昭和 $38 \sim 59$ 年に阪大 2 外で治㾤切除の行われた 初回入院胃癌患者,（）内は早期胃癌

\begin{tabular}{|c|c|c|c|c|c|}
\hline$R$ & 1 & $\mathbf{I}$ & $\mathbf{I}$ & $\mathbf{N}$ & It \\
\hline$R_{1}$ & $133(92)$ & $53(14)$ & 35 & 7 & $228(106)$ \\
\hline$R_{2}$ & $211(155)$ & $61(16)$ & $105(10)$ & 7 & $324(18))$ \\
\hline$R_{3}$ & $109(51)$ & $97(11)$ & $166(9)$ & $59(3)$ & $431(74)$ \\
\hline$R^{4}$ & $453(298)$ & $211(41)$ & $306(19)$ & $73(3)$ & $1043(361)$ \\
\hline
\end{tabular}


瘾切除術後の生存率曲線を図 1 亿示す。累積生存率で は $\mathrm{R}_{1}, \mathrm{R}_{2}, \mathrm{R}_{3}$ 切除群の生存率曲線は互い流わりあい 有意差はまったく認められないが，相対生存率では， 術後 6 年 $/ 10$ 年の $R_{1}, R_{2}, R_{3}$ 切除群はそれぞれ $98.55 \pm$ $3.37 \% / 98.18 \pm 4.52 \%, 94.85 \pm 2.74 \% / 91.12 \pm$ $4.08 \% ， 91.85 \pm 3.82 \% / 89.78 \pm 5.01 \%$ となり $\mathrm{R}_{1}$ 切除 群は $\mathrm{R}_{2}, \mathrm{R}_{3}$ 切除群よりも遠隔成績が良好といら傾向 が認められた。 そこで stage I 胃癌の絶対治癒切除術 後のグループより,深達度 $\mathrm{m}$ 早期胃癌のみを抽出し， それぞれR別の予後を検討した。

stage I 深達度 $m$ の早期胃癌 150 例の絶対治癒切除後 の累積生存率では $R_{1}, R_{2}, R_{3}$ 切除群相互には有意差は 認められない，ところが，相対生存率では術後 6 年/ 8 年の $\mathrm{R}_{1}, \mathrm{R}_{2}, \mathrm{R}_{3}$ 切除群はそれぞれ108.41士3.65\%/

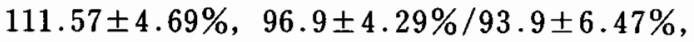
$101.74 \pm 4.33 \% / 103.36 \pm 4.40 \%$ となり $\mathrm{R}_{1}$ 切除群は $\mathrm{R}_{2}$ 切除群よりも明らかに $(\mathrm{p}<0.05)$ 予後が良く, $\mathrm{R}_{3}$ 切 除群は $R_{1}, R_{2}$ 切除群の中間に位置しているという結 果になった（図 2 ).

図 3 は stage II 胃癌211例の治㾤切除術後の生存率 曲線である. stage II 胃癌の絶対治痒切除群166例の 5

図 1 stage I 胃癌の絶対治癁切除術後の生存率曲線 粗生存事 相対生存事
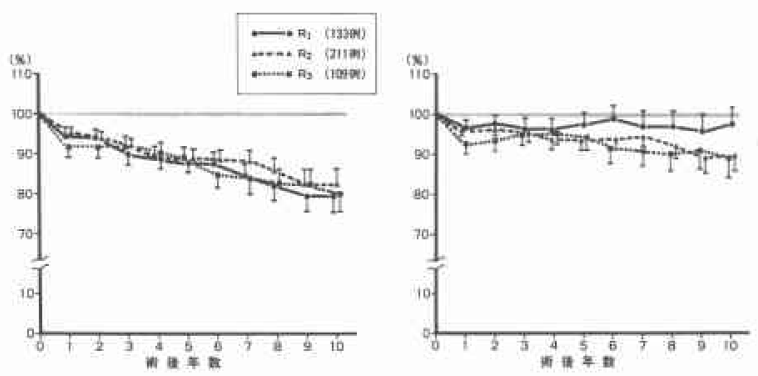

図 2 深達度mの stage I 早期胃癌の絶対治癒切除術 後の生存率曲線
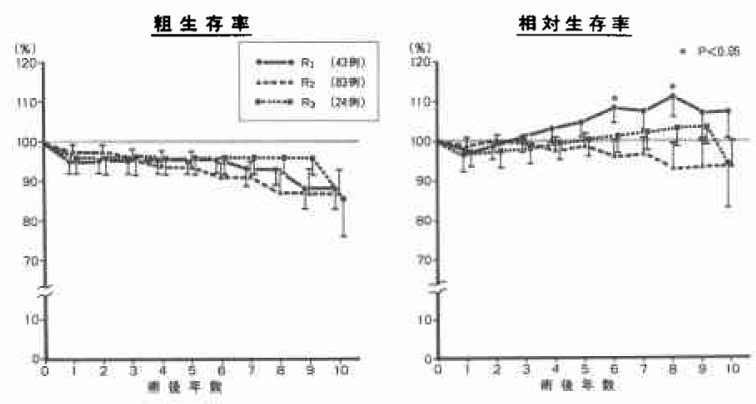

年/10年累積抢よび相対生存率はそれぞれ69.72士 $3.82 \% / 60.75 \pm 4.65 \%$ 打よび75.64 $44.14 \% / 69.78 \pm$ $5.34 \%$ で, 相対治庱切除群45例では $47.00 \pm 7.61 \% /$ $32.90 \pm 7.19 \%$ および $54.43 \pm 8.81 \% / 44.79 \pm 9.79 \% て ゙$ あった。したがって stage II 胃癌では粗生存率と相対 生存率のいずれにおいても絶対治瘜切除群の方が相対 治瘷切除群よりも明らかに生存率が高かったが，相対 生存率上りる粗生存率の方に高度の有意差が認められ た.この stage II 胃癌211例より， $\mathrm{n}_{1}(+) の$ stage II 早期胃癌のみ 41 例を抽出し， $\mathrm{R}$ 別の生存率を KaplanMeier 法により算出したのが図 4 である。やはり絶対 治癒切除群 $\left(\mathrm{R}_{2}\right.$ 切除群16例, $\mathrm{R}_{3}$ 切除群11例) の方が相 対治窑切除群 ( $\mathrm{R}_{1}$ 切除群 14 例) よりも生存率が高く, 術後 9 年・10年の $\mathrm{R}_{2}$ 切除群拉よび $\mathrm{R}_{1}$ 切除群の生存率

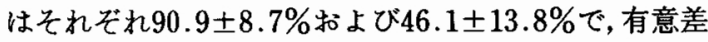
(p<0.01) が認められた.

stage III 胃癌306例の治癒切除術後の生存率曲線を 図 5 亿示す. stage III 胃癌の絶対治癒切除群216例の 5 年/10年累積および相対生存率はそれぞれ $45.25 \pm$ $3.55 \% / 33.47 \pm 3.69 \%$ 抢よび $49.18 \pm 3.86 \% / 39.54 \pm$ $4.36 \%$ で, 相対治痹切除群 90 例では $29.16 \pm 5.24 \% /$

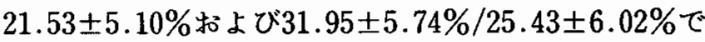
あった. stage II 胃癌と同様に, stage III 胃癌でも粗

図 3 stage II 胃癌の治療切除術後の生存率曲線

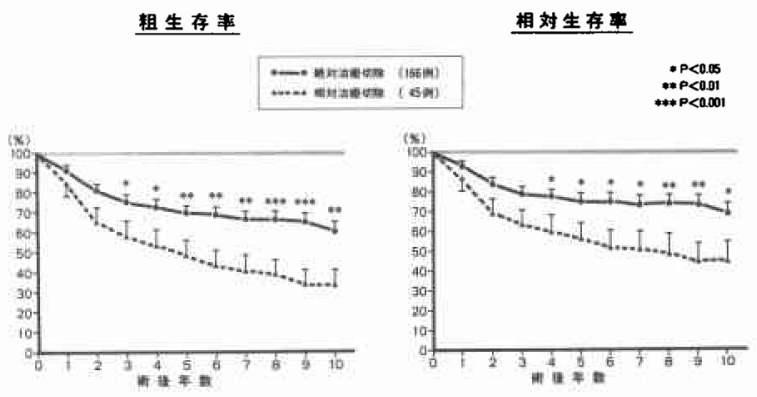

困 4 stage II 早期胃癌の治癋切除術後の生存率曲線

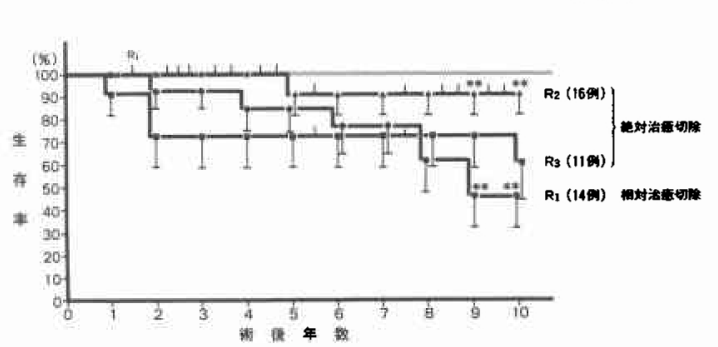


図 5 stage III 胃癌の治瘜切除術後の生存率曲線

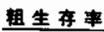

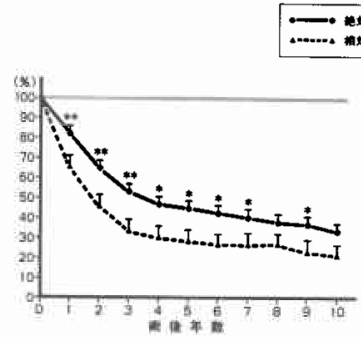

図 6 stage IV 胃癌の治瘄切除術後の生存率曲線 粗生存率

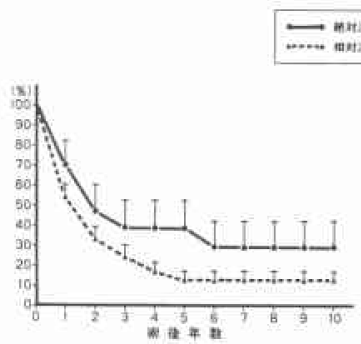

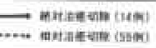
相对生存率

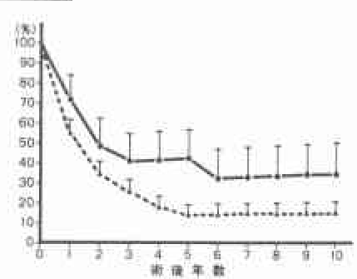

生存率々相対生存率のいずれにおいても䋓対治瘾切除 群の方が相対治癒切除群よりも有意に生存率が高かっ た。

治瘾切除術の行われた stage IV 胃癌73例の生存率 曲線を図 6 亿示す. stage IV 胃癌の絶対治癒切除群14 例と相対治瘦切除群 59 例の 5 年 $/ 10$ 年累積生存率はそ

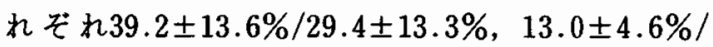
$13.0 \pm 4.6 \%, 5$ 年 $/ 10$ 年相対生存率は $42.4 \pm 14.7 \% /$ $34.8 \pm 15.7 \%, 14.2 \pm 5.0 \% / 15.6 \pm 5.5 \%$ ，いずれに も有意差は認められなかった。

\section{考案}

胃癌切除術後の残存所属リンパ節の抗腫瘍能を評価 するため, 同一 stage の胃癌治瘄切除術後患者につい $\tau, \mathrm{R}_{1}, \mathrm{R}_{2}, \mathrm{R}_{3}$ の郭清程度別に, その遠隔成績を比較し た.

リンパ節転移のない stage I 胃癌の絶対治瘾切除 453例に招いては $\mathrm{R}_{1}$ 切除群の相対生存率は $\mathrm{R}_{2}, \mathrm{R}_{3}$ 切除 群のそれよりも高くなる傾向が認められた(図 1)。そ こでこれらの stage I 胃癌のなかでも最も進行程度の 低い深達度 $\mathrm{m}$ の早期胃癌の絶対治痹切除 150 例の $\mathrm{R}$ 別 相対生存率を算出したところ $R_{1}$ 切除群は $R_{2}$ 切除群よ りも有意に高かった. そして $\mathrm{R}_{3}$ 切除群は $\mathrm{R}_{1}, \mathrm{R}_{2}$ 切除群 の中間に位置していた(図 2)。したがって、リンパ節 転移のないstage I 胃癌では所属リンパ節に十分な抗 腫瘍性 ${ }^{23)}$ が保持されており, リンパ流域所属リンパ節 の免疫応答能は腫瘍巣に近いリンパ節ほど高い2)の で, 残存所属リンパ節の抗腫瘍能が有効に発揮される ように, リンパ節郭清は最少限度にとどめるべきであ る.しかしながら，所属りンパ節の抗腫瘍的な免疫能 は, 転移の有無にかかわらず第 1 群, 第 2 群といら胃 癌近位のリンパ節に括いては第 3 群といら遠位リンパ 節に比較して低下しているので, 第 2 群リンパ節まで の系統的な郭清を推奖する報告4) 歹るる。

stage II (211例), stage III (306例) 胃癌では，累積 生存率に拈いても相対生存率に打いても，いずれる絶 対治癒切除群が相対治瘾切除群よりも有意に生存率が 高かった（図 3，5）. stage II 胃癌のグループより $\mathrm{n}_{1}$ (+)の stage II 早期胃癌のみ41例を抽出し， R 別生存 率を算出したところ, やはり絶対治疾切除群 $\left(\mathrm{R}_{2}, \mathrm{R}_{3}\right.$ 切除群) の方が相対治撚切除群 ( $\mathrm{R}_{1}$ 切除群) 上りる高 $く, \mathrm{R}_{2}$ 切除群之 $\mathrm{R}_{1}$ 切除群の間には有意差が認められ た(図 4 ). 癌腫が進行したものほど, その所属りンパ 節における抗腫痬的な免疫能は低下している244)とい ら報告がある一方で, リンパ節転移陽性の胃癌症例に は所属リンパ節の免疫能の上昇が認められるという報 告3)もあるのであるが，十分なリンパ節郭清を行って 癌細胞の遺残の可能性をなるべく少なくすることが遠 隔成績の向上に寄与していると考穴られる。

stage IV 胃癌73例については, 累積生存率と相対生 存率のいずれにおいても, 絶対治痹切除群と相対治瘾 切除群には有意差は認められなかった。ところが相対 治㾤切除群 59 例を $\mathrm{R}_{3}$ 切除群 46 例と $\mathrm{R}_{1}, \mathrm{R}_{2}$ 切除群 13 例 に分け，その 1 年/ 3 年 $/ 5$ 年累積生存率を表示すると ( 5 年以後 10 年までの死亡はない)，それぞれ60.9土 $7.2 \% / 27.0 \pm 6.7 \% / 16.9 \pm 5.8 \%$ お び $30.8 \pm 12.8 \% /$ $15.4 \pm 10.0 \% / 0 \%$ となり 1 年累積生存率では $\mathrm{R}_{3}$ 切除 群が有意に $(\mathrm{p}<0.05)$ 高かった。 stage IV 胃癌に打い ては遠隔リンパ節に抗腫場性の増強が期待できること を示唆する報告3すあるが，やはり系統的なリンパ節 郭清により遺残癌細胞を少なくすることに意義がある と考党られる。

以上の所見は胃癌手術の合理化に関して明解な指標 となるすのではあるが，手術施行時にリンパ節転移の 有無を的確に判定しえない現在，できるだけ遺残癌細 胞を少なくするという意味に扔いて所属りンパ節の十 分な郭清が必要と考えられる。昭和 38 年より 59 年まで の22年間に当科で手術を行った早期胃癌 372 例のうち 
$\mathrm{n}(-) 301$ 例 $81.0 \%, \mathrm{n}_{1}(+) 41$ 例11.0\%, $\mathrm{n}_{2}(+) 21$ 例 $5.6 \%, \mathrm{n}_{3}(+) 5$ 例 $1.3 \%, \mathrm{~N}_{4}, \mathrm{H}_{3}$, 拉上び肺転移 4 例 $1.1 \%$ であったので, 早期胃癌においても所属りン パ節郭清の重要性に変りはない。

$$
\text { まとめ }
$$

同一 stage の胃癌治瘾切除術後患者について, $\mathrm{R}_{1}$, $\mathrm{R}_{2}, \mathrm{R}_{3}$ の郭清程度別に遠隔成績を比較することによ $\eta$ ，残存所属リンパ節の抗腫煌能を検討した.

1）リンパ節転移のない stage I 胃癌では $R_{1}$ 切除群 の相対生存率が $R_{2}, R_{3}$ 切除群よりも高くなる傾向が 認められるところから, 残存所属リンパ節の抗腫瘍能 の存在が推測されるので, この抗腫瘍能が有効に発揮 されるように, 所属リンパ節郭清は最少限度にとどめ るべきである.

2) stage II, III 胃癌では, 累積生存率々相対生存率 のいずれに打いても，絶対治瘾切除群が相対治空切除 群よりも有意に生存率が高かったので，十分なリンパ 節郭清を行って癌細胞の遺残をなるべく少なくするこ とが遠隔成績の向上に寄与していると考穴られる。

3) stage IV 胃癌では, 累積生存率々相対生存率の いずれに括いても, 絶対治瘾切除群と相対治瘾切除群 の有意差は認められなかったが，相対治庱切除群では $\mathrm{R}_{3}$ 切除群の累積生存率が $\mathrm{R}_{1}, \mathrm{R}_{2}$ 切除群上りも有意に 高かったので，やはり十分なリンパ節郭清により遺残 癌細胞を少なくすることに意義があると考えられる.

\section{文献}

1) Kurokawa $Y$ : Experiments on lymph node metastasis by intralymphatic inoculation of rat ascites tumor cells, with special reference to lodgement, passage, and growth of tumor cells in lymph nodes. Gann $61: 461-471,1970$

2）菅沼 靖, 阿部力哉, 渡辺 至ほか：胃癌患者所属 リンパ節リンパ球の PHA 刺激試験. PWM 刺激 試験および RLB 試験による免疫学的検討. 日澏治 療会誌 $11: 193-202,1976$

3）松本 学, 小玉正智, 寺田信国ほか：胃癌患者に打 ける領域リンバ節の免疫応答. 癌の臨 26 ： 270-274, 1980

4）小川健治：胃癌所属リンパ節の機能的, 形態的抗 腫場性に関する研究。日臨外医会誌 42 ： 101-113， 1981

5) Black MM, Freeman C, Mork $T$ et al: Prognostic significance of microscopic structure of gastric carcinomas and their regional lymph nodes. Cancer $27: 703-711,1971$

6) Cutler SJ, Ederer F: Maximum utilization of the life table method in analyzing survival. J Chron Dis 8: 699-712, 1958

7) Kaplan EL, Meier P: Nonparametric estimation for incomplete observation. J Am Stat Assoc 53 : 457-481, 1958

8）小池淳夫, 田代節春：コホート生存率表. 厚生の指 標 $23: 14-17,1977$

9）栗原 登, 高野 昭：癌の治撚率の計算方法につ いて一相対生存率の意義と算出法. 癌の臨 11 : 628-632, 1965 